\title{
Occupant Expectations on the Main IEQ Factors at Workspace: The Studies of Private Preschool Buildings
}

\author{
Naziah Muhamad Salleh ${ }^{1 a}$, Nuzaihan Aras Agus Salim ${ }^{1}$, and Syahrul Nizam Kamaruzzaman ${ }^{2}$ \\ ${ }^{1}$ University Science Malaysia, School of Housing Building \& Planning, Building Survey Department, 11800 Penang, Malaysia \\ ${ }^{2}$ University of Malaya, Faculty of Built Environment, Building Performance and Diagnostic, 50603 Kuala Lumpur, Malaysia
}

\begin{abstract}
This study explores the relationship between the perceived performance of specific IEQ factors and occupants' overall satisfaction with their workspace. The Indoor Environmental Quality (IEQ) in buildings is one of the most important factors affecting the physical development of children. The early education is compulsory and escalated numbers of 4-6 years children has boosted the numbers of private preschool. Frequently its operate in premises that have been fully refurbished, either in housing schemes, commercial buildings or institutional buildings. This has invited the questions on the building capability to provide a good environment to the children during the learning activities. Malaysia still lacks studies on the modification of the quality of the internal environment for private kindergartens. Post-Occupancy Evaluation (POE) is one method that has been used satisfactorily in the study and effect of IEQ in kindergartens. This research focuses on identifying occupant satisfaction towards IEQ in selected refurbished pre-school or kindergarten buildings. The objectives of the study are to identify and determine the IEQ through feedback from building users. The study collected data on overall satisfaction and overall design importance through building inspection and questionnaires, the data obtained was analyzed to become a benchmark for the studies. 240 kindergartens in the whole country were selected for the study of IEQ.
\end{abstract}

Keywords: Indoor Environmental Quality, Post-Occupational Evaluation, Refurbishment, Preschool, Occupants Perception

\section{Introduction}

Several researchers have demonstrated that if people work in good environmental conditions, their productivity The and health improve (Gao et al., 2014, Rosen, 2009, Ambu, 2008, Uline and Moran, 2008, Stankovic and Stojic, 2007, Wargocki et al., 2005, Mendell, 2004, Schneider, 2002). The early aim is a need of achieving a good comfort level in educational buildings. It is due to the fact that children spending around $30 \%$ of their life span in schools (Lee and Chang, 1999).

Comfort and health levels are arising issues, while the occupants are in the buildings. Given the impact of the school environment on health, numerous researchers (Salleh et al., 2015; Montzamani et al., 2012; Puteh et al., 2014; Mendel et al., 2004; Salleh et al., 2013; Kabir et al., 2011) have identified building characteristics that affect the occupants' health and performance,

\footnotetext{
a Corresponding author: naziahmsalleh@usm.my
}

including indoor air quality, temperature, odours or olfactory effects, visuals, acoustics, daylight and artificial lighting, ergonomics and space. Where several of these features are inadequate, it is difficult to identify the actual direct causes of occupant discomfort and health symptoms [Sulaiman et al., 2013; Bluysen, 2009; Chiang and Lai, 2002). However, some studies have already delved into indoor environmental conditions in educational buildings (Salleh et al., 2015; Gao et al., 2014, Sulaiman et al., 2013, Mydin et al., 2012, Nasir et al., 2011, Mumovic, 2009).

With increased awareness of occupants' productivity regarding environmental perceptions (Mendel et al., 2013; Jarman et al., 2004; Soughnessy et al., 2006), various models have been established to obtain the occupants' feedback: Leadership in Energy and Environmental Design (LEED), Green Building rating systems, Building Research Establishment Environmental Assessment Methods (BREEAM), Hong Kong Building 
Environmental Assessment Method(HK-BEAM) and the TOBUS decision-making tool for upgrading office buildings. These systems are reliable in assessing and enhancing the IEQ of buildings. Indoor air quality, thermal comfort and acoustic performance of recently built schools (Mumovic, 2009) were evaluated by means of field measurements. Another study (Mors et al., 2011) focused on the actual thermal sensitivity and clothing insulation of children in none air-conditioned classrooms by means of both physical measurements and questionnaires.

In Malaysia most of the studies performed in public schools were organised by the government (Kamaruzzaman and Rasitah, 2011, Junaidah et al., 2010, Hussin et al., 2011). The buildings and facilities are well-prepared by the authorities that adhere to the standards provided. However, unlike the private preschools in Malaysia, the facilities and school buildings are provided by the individual person or non-government organisations (NGO). They are generally operated in re-adaptive buildings such as housing premises (KL City Hall, 2010). The bedrooms are converted to classrooms; therefore it used to be a challenge to provide an adequate environment for the children.

The broad aim of this paper is to determine the correlation between performance in refurbished private preschools and staffs' expectation on satisfaction and expectations levels, using the POE approach and guidelines. The objectives of this study are accordingly: i) to determine the satisfaction level of the building's occupants in terms of indoor environment and ii) to identify any correlation between individuals' expectations and their perception of the environment. The outcomes of the study are intended to be used as a benchmark for the improvement of private pre-schools in Malaysia.

\section{Methods and Materials}

In order to obtain a higher response rate, the questionnaire was designed to be only four pages long. It used a simple presentation that would not take long for the respondents to answer. Space was provided for the respondents to give additional comments. Before the questionnaire was sent out, it was piloted with 10 po- tential respondents from two pre-schools, whose comments and suggestions were taken into consideration in the final version.

Covering letters and questionnaires were distributed by hand to school administrative staff, to gain permission. The questionnaires were then collected within two weeks, during the building observation. Of the 1,020 questionnaires distributed around Peninsular Malaysia (to 5-7 staff, in 240 pre-schools; 711 classrooms); 521 were returned, of which 57 remained unanswered and 60 were incomplete. That is, 404 questionnaires were found to be useful. These figures are summarized in Table 1.

Table 1. The questionnaire survey

\begin{tabular}{l|l|}
\hline Description & \multicolumn{1}{l}{$\begin{array}{l}\text { Fre- } \\
\text { quency }\end{array}$} \\
\hline Number of questionnaires sent out & 1020 \\
\hline Total returned questionnaires & 521 \\
\hline $\begin{array}{l}\text { Questionnaire sets returned without an- } \\
\text { swers }\end{array}$ & 57 \\
\hline Questionnaire sets returned uncompleted & 60 \\
\hline Overall percentage returned & $51.08 \%$ \\
\hline Valid percentage returned & $39.61 \%$ \\
\hline
\end{tabular}

The valid response rate recorded was almost $40 \%$, which is sufficient for a social science study in Malaysia (Sarantakos, 2012). Krejic and Morgan's (1970) table to determine sample size shows that, for a population of 1,100 , the minimum acceptable size is 285 . In this study, the response rates of 408 can justifiably represent the total population.

The questionnaire has two sections: Section A asked for general information about age, gender, work experience, etc., and Section B explored attitudes to the 21 factors relating to the internal environment of the building as listed below (Q1 to Q21). The occupants were asked to rate their answers on a seven-point Likert scale for "User satisfaction" and "Degree of importance". The results were used to elicit an occupant satisfaction score and a benchmark for building satisfaction.

$\begin{array}{ll}\text { Q1 } & \text {-Noise level } \\ \text { Q2 } & \text {-Electric lighting } \\ \text { Q3 } & \text {-Amount of daylight } \\ \text { Q4 } & \text {-Glare level in the room } \\ \text { Q5 } & \text {-Distance to the windows } \\ \text { Q6 } & \text {-Room temperature } \\ \text { Q7 } & \text {-Ventilation } \\ \text { Q8 } & \text {-Amount of air movement }\end{array}$

\author{
-Health when in the room \\ -Colours of the room \\ -Attractiveness of the room \\ -Control over local environment \\ -Workspace \\ -Privacy \\ -Immediate colleagues \\ -Management
}




$$
\begin{array}{ll}
\text { Q9 } & \text {-Freshness of your room } \\
\text { Q10 } & \text {-Humidity level in the room } \\
\text { Q11 } & \text {-Smell in the room }
\end{array}
$$

Analysis methods utilised to answers to the questionnaire indicate the occupants' ratings of their satisfaction with the internal environment, and how important they find these environmental conditions. The first part of the analysis determines the satisfaction score of a building (an overall rating for a building's indoor environment) using Equation 1:

$$
\mathrm{OLS}=\left[\frac{\sum_{\mathrm{k}=1}^{\mathrm{n}} \sum_{\mathrm{j}=1}^{\mathrm{m}} \mathrm{i}_{\mathrm{j}, \mathrm{k}} 1_{\mathrm{j}, \mathrm{k}}}{\mathrm{mn \textrm {i } _ { \text { max } } 1 _ { \operatorname { m a x } }}}\right] 100
$$

where

$$
\begin{aligned}
& \mathrm{j}=\text { questionnaire number } \\
& \mathrm{k}=\text { question number } \\
& \mathrm{i}=\text { importance rating } 1<\mathrm{i}>7 \\
& \mathrm{i}_{\max }=\text { maximum value of } \mathrm{i},(7) \\
& \mathrm{l}_{\max }=\text { maximum liking rating } 1(+3) \\
& \mathrm{l}=\text { liking rating }-3<1>+3 \\
& \mathrm{~m}=\text { number of completed questionnaires } \\
& \mathrm{n}=\text { number of questions in the score }
\end{aligned}
$$

The second part of the analysis provides a graphical representation of the totals for each answer. This is called a "user satisfaction fingerprint" and normalizes each question to a score from $+100 \%$ to- $100 \%$ (Levermore, 1994, 1994a, 1999, 2000), using Equation 2.



The third part of the analysis is similar to the second. However, using Equation 3, a normalized individual score for each person can be calculated.

$$
\begin{array}{ll}
\text { Q20 } & \text {-Workplace, in general } \\
\text { Q21 } & \text { - Outward appearance }
\end{array}
$$

$$
\mathrm{FLS}=100\left[\frac{\sum_{\mathrm{k}=1}^{\mathrm{n}} \mathrm{i}_{\mathrm{j}, \mathrm{k}} 1_{\mathrm{j}, \mathrm{k}}}{n \mathrm{i}_{\text {max }} 1_{\max }}\right]
$$

This score will be between $+100 \%$ and $-100 \%$.

A building walk-through form was used by the research team to compile an inventory of the building materials and contents of the classrooms. Data were collected to characterize the materials and condition of the ceiling, floor, interior walls, exterior walls, Heating, Ventilation and Air Condition (HVAC) equipment, and classroom contents. These were the items most frequently identified as sources of IEQ problems during the building inspections. Location of the building from the main road, surrounding activities, number of pupils in a classroom, mold, damp, the volume of the classrooms, and ventilation systems were also cited.

\section{Results and Discussions 3.1 Building Observation}

The building survey was correlated with the perceptions of the occupants towards the building. Of the 240 participating private pre-schools, $92.9 \%$ are operating in refurbished residential premises, mostly rented two-storey terraced houses (67.1\%) with 100-199 $\mathrm{m}^{2}$ of floor area. Two-thirds of the buildings are located on medium-local streets with moderate traffic flow, less than $50 \mathrm{~m}$ from the premises. Surprisingly, $96.6 \%$ of the classrooms $(\mathrm{N}=711)$ identified did not comply with the Uniform Building Bylaw (UBBL, 2012), requirement for space per person in classrooms. The descriptive analysis of building observations is detailed in Table 2 . The most frequent occurrence of each characteristic is shown in bold.

Table 2. Descriptive analysis of preschool buildings

\begin{tabular}{|l|l|c|}
\hline \multicolumn{1}{|c|}{ Categorical Variables (N=25) } & \multicolumn{1}{|c|}{ Description } & Percent (\%) \\
\hline Building types & Single Terrace & 11.0 \\
& Double Terrace & $\mathbf{6 7 . 1}$ \\
& Single Bungalow & 4.6 \\
& Double Bungalow & 10.1 \\
& Shop/office & 0.8 \\
& Others & 6.3 \\
\hline
\end{tabular}




\begin{tabular}{|c|c|c|}
\hline Ownership of the building & $\begin{array}{l}\text { Owned } \\
\text { Rented }\end{array}$ & $\begin{array}{l}34.2 \\
65.8\end{array}$ \\
\hline Age of the building (years) & $\begin{array}{l}<5 \\
5-10 \\
\mathbf{1 0 - 1 5} \\
15-20 \\
20-30 \\
>30\end{array}$ & \begin{tabular}{c|}
5.9 \\
28.7 \\
$\mathbf{3 3 . 3}$ \\
14.3 \\
16.0 \\
1.7
\end{tabular} \\
\hline Programme & $\begin{array}{l}\text { Pre-school only } \\
\text { Daycare only } \\
\text { Pre-school+Daycare } \\
\text { Pre-school+Tuition } \\
\text { Pre-school+Daycare+Tuition }\end{array}$ & $\begin{array}{c}\mathbf{5 8 . 2} \\
3.4 \\
30.8 \\
3.4 \\
4.2\end{array}$ \\
\hline Age of pupils & $\begin{array}{l}>4 \text { years } \\
4-6 \\
7-8 \\
>9 \\
\text { Infants(0 months-3years }) \\
\end{array}$ & $\begin{array}{c}1.7 \\
\mathbf{6 9 . 2} \\
1.3 \\
20.7 \\
7.2 \\
\end{array}$ \\
\hline Totalfloor area & $\begin{array}{l}<100 \mathrm{~m}^{2} \\
\mathbf{1 0 0 - 1 9 9 \mathbf { m } ^ { 2 }} \\
200-299 \mathrm{~m}^{2} \\
300-399 \mathrm{~m}^{2} \\
>399 \mathrm{~m}^{2}\end{array}$ & $\begin{array}{c}9.7 \\
\mathbf{7 9 . 3} \\
7.2 \\
3.0 \\
0.8 \\
\end{array}$ \\
\hline \multicolumn{2}{|c|}{ Classroom floor area (mean \pm standard deviation) } & $15.51 \pm 5.98 \mathrm{~m}^{2}$ \\
\hline \multicolumn{2}{|c|}{ Open area per classroom (mean \pm standard deviation) } & $5.30 \pm 1.53 \mathrm{~m}^{2}$ \\
\hline \multicolumn{2}{|c|}{ Numbers of pupils and teachers per classroom (mean \pm standard deviation) } & $16 \pm 4$ \\
\hline Required space (minimum $2 \mathrm{~m}^{2}$ per person) & $\begin{array}{l}\text { not compliedwith }(<) \\
\text { complied with }\end{array}$ & $\begin{array}{c}96.6 \\
3.4\end{array}$ \\
\hline Ventilation type & $\begin{array}{l}\text { Dominantly natural } \\
\text { Dominantly air-conditioned } \\
\text { Both }\end{array}$ & $\begin{array}{l}33.8 \\
\mathbf{3 6 . 3} \\
29.9\end{array}$ \\
\hline Traffic type & $\begin{array}{l}\text { Small local street } \\
\text { Medium local street } \\
\text { Large local street } \\
\text { Expressway }\end{array}$ & $\begin{array}{c}12.7 \\
\mathbf{6 5 . 0} \\
16.0 \\
6.3 \\
\end{array}$ \\
\hline Traffic density & $\begin{array}{l}\text { Low } \\
\text { Medium } \\
\text { Heavy }\end{array}$ & $\begin{array}{l}30.4 \\
\mathbf{5 4 . 9} \\
14.8 \\
\end{array}$ \\
\hline Floor surface & $\begin{array}{l}\text { Smooth } \\
\text { Carpeted }\end{array}$ & $\begin{array}{l}\mathbf{8 4 . 8} \\
15.2 \\
\end{array}$ \\
\hline Curtain type & $\begin{array}{l}\text { None } \\
\text { Blinds } \\
\text { Textiles }\end{array}$ & $\begin{array}{c}62.9 \\
7.6 \\
29.5 \\
\end{array}$ \\
\hline Recent renovation & Yes & 54.4 \\
\hline Cooking activities & Yes & 70.9 \\
\hline Dampness & Yes & 52.3 \\
\hline Mould growth & Yes & 54.0 \\
\hline Vermin absent & Yes & 76.0 \\
\hline Soft toys & Yes & 85.2 \\
\hline $\begin{array}{l}\text { Continue Table } 2 \\
\text { Categorical Variables }(\mathrm{N}=\mathbf{2 5})\end{array}$ & Description & Percent (\%) \\
\hline Floor cleaning & $\begin{array}{l}\text { Twice a day } \\
\text { Daily }\end{array}$ & $\begin{array}{l}30.4 \\
69.6 \\
\end{array}$ \\
\hline Fan cleaning & $\begin{array}{l}\text { Twice a week } \\
\text { Weekly } \\
\text { Monthly }\end{array}$ & $\begin{array}{c}8.0 \\
85.0 \\
26.5\end{array}$ \\
\hline Shelf cleaning & $\begin{array}{l}\text { Daily } \\
\text { Twice a week } \\
\text { Weekly }\end{array}$ & $\begin{array}{l}28.7 \\
19.8 \\
51.5\end{array}$ \\
\hline
\end{tabular}




\begin{tabular}{|l|l|c|}
\hline Table cleaning & Daily & 66.2 \\
& Twice a week & 28.7 \\
& Weekly & 5.1 \\
\hline Toilet cleaning & Daily & 78.5 \\
& Twice a week & 19.8 \\
& Weekly & 1.7 \\
\hline Curtain cleaning & Weekly & 6.3 \\
& Monthly & 46.4 \\
& Bi-annually & 26.6 \\
& Never & 20.7 \\
\hline
\end{tabular}

\subsection{Staff's Expectation}

The staff offered their opinions on the degree of each IEQ factor experienced in their building. Figure 1 shows the satisfaction scores for all the buildings, with question 1 (noise) having the worst score and the only negative one, and question 18 (colleagues) the best The highest-scoring satisfaction subject areas are shown in Table 3.

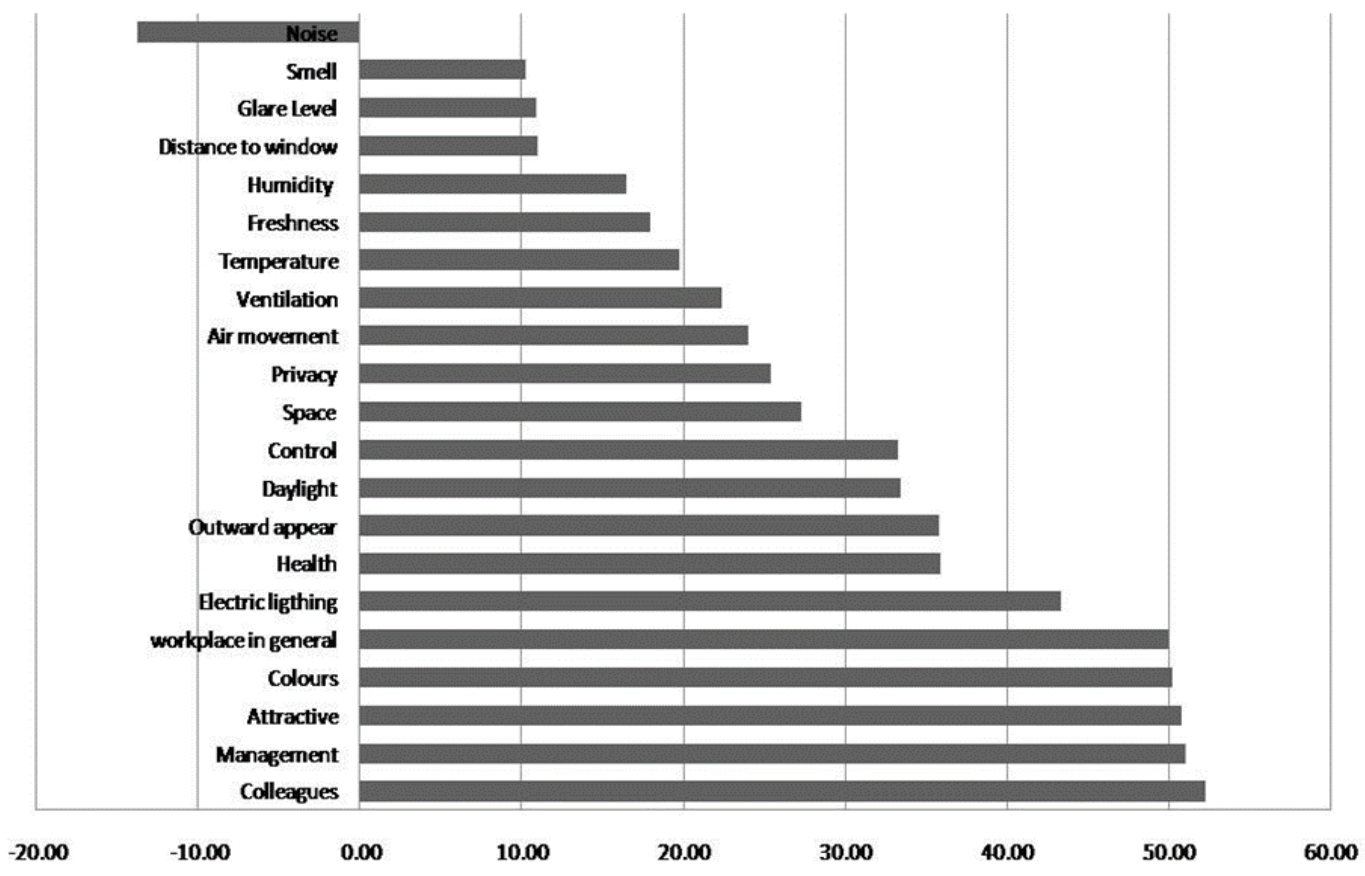

Figure 1, Audit satisfaction fingerprint

Table 3. Most satisfactory features

\begin{tabular}{|l|l|c|}
\hline Question No. & Question subject & Score \\
\hline 18 & Colleagues & +52.31 \\
\hline 19 & Management & +51.10 \\
\hline 14 & Attractive & +50.80 \\
\hline 13 & Colours & +50.22 \\
\hline 20 & Workplace in general & +50.02 \\
\hline
\end{tabular}


As most of the pre-schools have only 4 to 7 staff members, it is perhaps not surprising that the highest scores are in relation to immediate colleagues and management; there are strong bonds between the staff and ready interaction with management. Site observation indicated that walls painted in cheerful colours and decorated with various murals were attractive to pupils, and this feature was next highest on the list.

Even though all but one of the scores for the questionnaire are on the positive side, some are considered less favourably than others, as shown on Table 4.

Table 4. Least satisfactory features

\begin{tabular}{|c|l|c|}
\hline Question No. & Question subject & Score \\
\hline 1 & Noise & -13.77 \\
\hline 11 & Smell & +10.22 \\
\hline 4 & Glare level & +10.91 \\
\hline 5 & $\begin{array}{l}\text { Distance to } \\
\text { window }\end{array}$ & +10.96 \\
\hline 10 & Humidity & +16.51 \\
\hline 9 & Freshness & +17.95 \\
\hline 6 & Temperature & +19.73 \\
\hline 7 & Ventilation & +22.36 \\
\hline 8 & Air movement & +24.00 \\
\hline
\end{tabular}

The external noise level had the lowest score (13.77), not surprising given that all the buildings were in urban areas with a high volume of traffic, and in their previous roles were connected to main roads. There was also noise from within their own premises during teaching periods.

The buildings' occupants also gave less favourable scores for smell $(+10.22)$, humidity $(+16.50)$ and freshness $(\mathrm{s}+17.95)$, the three elements categorized as air quality factors. Overcowding in classrooms which had previously been bedrooms $(9 \mathrm{~m} 2-23 \mathrm{~m} 2)$ contributed to breathing difficulties and a smelly environment.

Air movement within the building was given a higher score $(+24.00)$, followed by ventilation $(+22.36)$ and temperature $(+19.73)$, whether or not resulting from air conditioning.

\subsection{Scores for Factors from the Questionnaires}

Analysis of variance (ANOVA) is applicable if the research has two groups or more to compare. Based on the five factor scores generated, a further analysis on the differences between each factor in the questionnaire was carried out. Using SPSS, One-way ANOVA and t-tests were performed to determine the statistical significance of differences among the means of the groups in six selected variables.

\section{a) Analysis one: Type of building}

The questionnaire had five sub-groups based on building types, as detailed in Table 6. An analysis of variance revealed significant differences at the $5 \%$ level in the appearance $[\mathrm{F}(4,403)=2.73, \quad \mathrm{p}=0.03]$ and intrusion $[F(4,403)=2.67, p=0.03]$ factor scores. On the other hand, there are non-significant differences at the $5 \%$ level in the air quality, general and workplace scores. Post hoc analyses using the Tukey HSD for significance indicated that the average number of errors was significantly lower in the bungalow condition towards general and intrusion factors than in the other four factors.

\section{b) Analysis two: Type of ventilation}

There were two major groups of ventilation: natural $(n=183)$ air conditioning $(n=221)$. The few hybrid/mixed ventilation systems were considered as air-conditioning, because most of the pre-schools turn on the air conditioning as early as 10 a.m., or whenever they felt the temperature increased in the building.

The t-test for independent samples revealed non-significant difference at the $5 \%$ level for other factors. This means that there is little difference between the two types of the ventilation.

\section{c) Analysis three: Work category}

The four sub-groups in the work category (see Table 2) were clerk (11), teacher (287), manager (79) and others (27; (includes teacher assistant, housekeeper, etc.). An analysis of variance revealed significant differences at the $5 \%$ level in intrusion $[\mathrm{F}(3,403)=4.9, \mathrm{p}=0.02]$. However, there were non-significant differences at the $5 \%$ level in the other factors. Post hoc analyses using the Tukey HSD for significance indicated that the average number of clerks had a higher opinion of intrusion than the "others" category.

\section{d) Analysis four: Age}

The six sub-groups under age are detailed in Table 6. An analysis of variance revealed non-significant differences at the 5\% level in all the factors, indicating that allege groups have the same opinion about the environmental factors.

\section{e) Analysis five: Number of people in the building}

See Table 6 for the four sub-groups based on number of people in the building. An analysis of variance revealed significant differences at the $5 \%$ level in the air quality $[\mathrm{F}(5,403)=7.22, \mathrm{p}=0.00]$, appearance $[\mathrm{F}(5,403)=2.43$, $\mathrm{p}=0.03]$ and workplace $[\mathrm{F}(5,403)=4.81, \mathrm{p}=0.00]$ factors. Post hoc analysis using the Tukey HSD for 
significance indicated that the mean scored for group of people in the building was lower compares to the group of 2 people towards the perception of air quality and the workplace in general. It is clear that crowded buildings will result in an unpleasant environment, linking freshness, smell, ventilation and temperature of the building, and affecting the opinion on the workplace in general.

Moreover, Figure 2 explains the negative relation between the dissatisfaction/dislike levels of perception and the total hours staff spend in the building. Suprisingly results for satisfaction level had a similar range, where time spent in the building alsohad a negative relation to the satisfaction level. In other words, the more time spent in the pre-school building, the greater the satisfaction of the occupants. Nevertheless, for some occupants more time spent in the building generated unpleasant feelings towards it. A similar result was found between the perception of the workplace and the class floor area.

Table 5 shows that the analysis of covariance for the perception of staff towards the workplace with the classroom floor area, time spent in the building and the duration of staff work in the same building has a nonsignificant relationship. This explains why these variables did not affect the satisfaction level while working in the pre-school buildings.

Table 5. Covariance Analysis

\begin{tabular}{lrrrrrrrrr}
\hline & \multicolumn{2}{c}{ Dislike } & \multicolumn{2}{c}{ Neutral } & \multicolumn{2}{c}{ Like } & & \\
\multicolumn{1}{c}{ Scale } & Mean & \multicolumn{1}{c}{ SD } & \multicolumn{1}{c}{ Mean } & SD & Mean & SD & F & df & $p$ value \\
\hline Class floor area & 16.48 & 5.26 & 16.01 & 3.88 & 15.12 & 4.50 & 1.23 & 2.00 & 0.05 \\
Total hours spent in building per day & 7.20 & 2.33 & 7.74 & 2.27 & 8.08 & 3.04 & 2.70 & 1.07 & 0.07 \\
Number of years working in the building & 5.75 & 4.90 & 5.54 & 3.43 & 6.19 & 5.17 & 0.73 & 2.00 & 0.48 \\
\hline
\end{tabular}

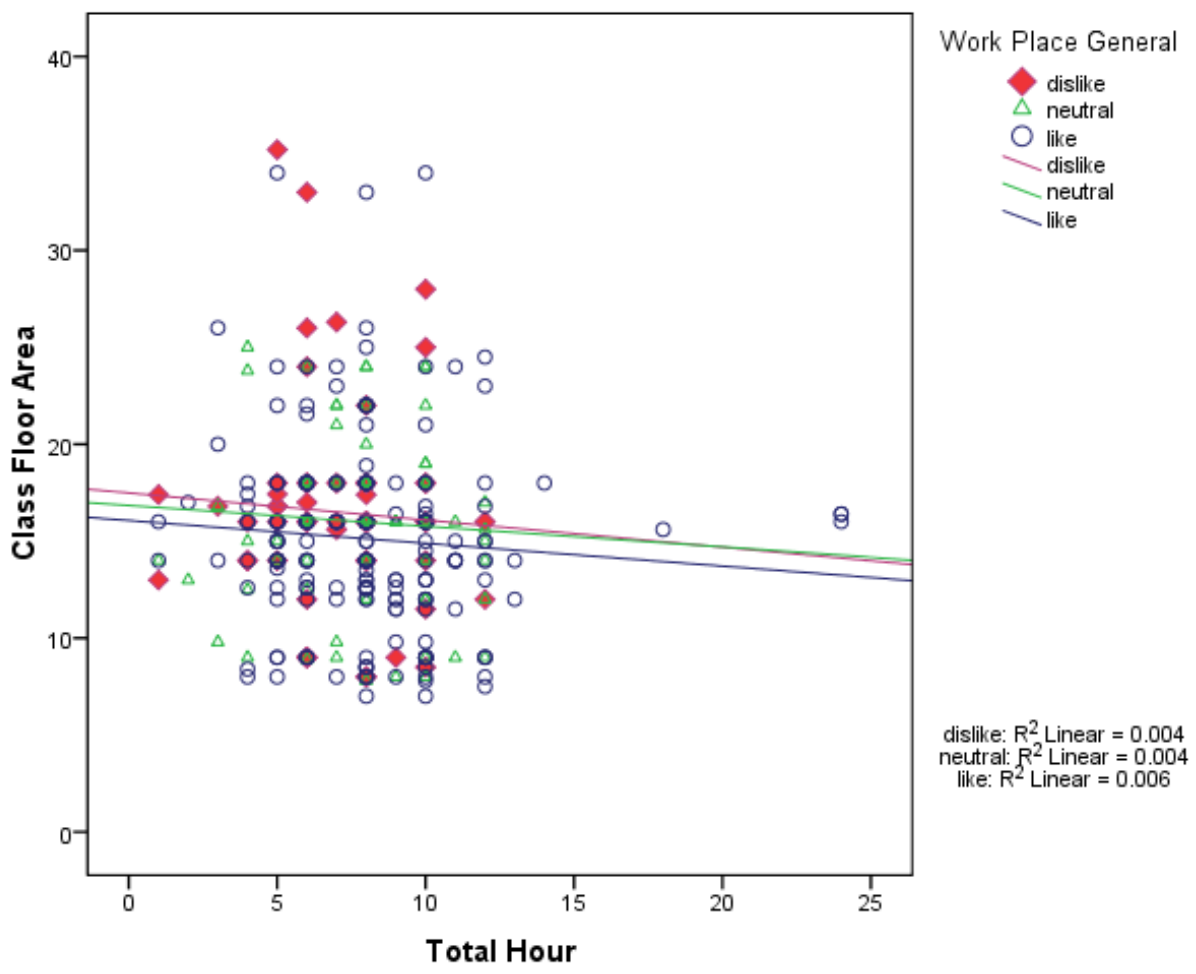

Figure 2. Scatter Plot of Total Hours Spend in the Building and the Class Floor Area with the Perception of the Building in General

\section{f) Analysis six: Time spent in the building}


The questionnaire had four sub-groups for the number of hours spent in the building each day. An analysis of variance revealed significant differences at the $5 \%$ level in the general factor $[F(4,403)=5.82, p=0.00]$. Post hoc analyses using the Tukey HSD for significance indicated that the mean score of the group spending 4-6 hours in the building was lower than that for those spending more than 10 hours there. This is due to the long time being exposed to the same environment, which might also affect the liking variable.

\section{g) Analysis seven; Classroom floor area and space requirement}

There were four sub-groups here $:<10 \mathrm{~m}^{2}(\mathrm{n}=46), 10$ $20 m^{2}(n=315), 20-30 m^{2}(n=39)$ and $>30 m^{2}(n=4)$. A one- way between subjects ANOVA was conducted to compare the effect of workplace/classrooms' floor area with the five factors of IEQ. There was a significant effect of floor area towards the classroom's external appearance at the $\mathrm{p}<.05$ level for all four groups $[\mathrm{F}(3$, $339)=2.837, p=0.04]$. Post hoc comparisons using the Tukey HSD test indicated that the highest mean score was for classrooms with a floor area more than $30 \mathrm{~m}^{2}$. The greater the floor area, the better the appearance. However, there is no significance between the space requirements per person and contribution to an unpleasant environment among the five factors determined earlier. Other variables caused discomfort to the occupants.

Table 6. Analysis of Total Variance

\begin{tabular}{|c|c|c|c|c|c|c|}
\hline SAMPLE & $\mathbf{N}$ & $\begin{array}{l}\text { AIR } \\
\text { QUALITY }\end{array}$ & GENERAL & APPEARANCE & INTRUSION & WORKPLACE \\
\hline Building type & $\mathrm{F}_{\mathrm{r}}$ & $* 0.77$ & $* 0.91$ & $* 0.03$ & $* 0.03$ & $* 0.51$ \\
\hline $\begin{array}{l}\text { Ventilation type } \\
\mathrm{NaV}=183 \\
\mathrm{AC}=221\end{array}$ & $\mathrm{t}_{1}$ & $* * 0.09$ & $* * 0.80$ & $* * 0.41$ & $* * 0.06$ & $* * 0.62$ \\
\hline Work category & $\mathrm{F}_{\mathrm{r}}$ & $* 0.72$ & $* 0.08$ & $* 0.80$ & $* 0.02$ & $* 0.86$ \\
\hline Age & $\mathrm{F}_{\mathrm{r}}$ & $* 0.07$ & $* 0.06$ & $* 0.10$ & $* 0.14$ & $* 0.82$ \\
\hline Number of people in Building & $\mathrm{F}_{\mathrm{r}}$ & $* 0.00$ & $* 0.90$ & $* 0.03$ & $* 0.16$ & $* 0.00$ \\
\hline Hours in building & $\mathrm{F}_{\mathrm{r}}$ & $* 0.69$ & $* 0.00$ & $* 0.46$ & $* 0.17$ & $* 0.07$ \\
\hline Classroom floor area & $\mathrm{F}_{\mathrm{r}}$ & $* 0.23$ & $* 0.11$ & $* 0.04$ & $* 0.69$ & $* 0.11$ \\
\hline $\begin{array}{l}\text { Space/person } \\
\text { requirement }\left(<2 \mathrm{~m}^{2} / \text { person }\right) \\
\text { Not complied with: } 372 \\
\text { Complied with: } 32 \\
\end{array}$ & $\mathrm{t}_{1}$ & $* 0.14$ & $* 0.25$ & $* 0.14$ & $* 0.14$ & $* 0.45$ \\
\hline $\begin{array}{l}F_{r}=F \text { ratio } \\
p<0.05\end{array}$ & & is of Varia & & & t sample & \\
\hline
\end{tabular}

\section{Conclusions}

Most refurbished preschool building in Malaysia were found not to comply with minimum space regulation concerning children, teachers and staff, leading to the uncomfortable conditions and spreading out the infectious illness. It is suggested that the authorities to take this issues into consideration and provide the sufficient space for the occupants. It is also to put into account the location of the classrooms and schools when the premises being converted to the education buildings.

From this research, it can be concluded that Post Occupancy Evaluation emphasizes the significance of improving Indoor Environment Quality in the refurbished preschool's buildings. There is still lack of awareness toward the significance of IEQ, and half of the respondents

the majority were the buildings' owners) admitted they never bothered about IEQ in their buildings. Some also admitted that they had refurbished the building without referring to the guidelines from the local authority and might as well invited some contaminations and organics effluences such as polluted gases, mold and fungi into the building.

The current scenario preschool buildings in Kuala Lumpur are concerns on minimalist of IEQ consideration, neglecting to study the buildings' characteristics and the indoor environment for early education. Nevertheless, the study found 
that half of the building owners followed the guidelines from the local authority, and some buildings had the initiative to implement the guidelines. This is one of the approaches that are quite relevant, but proper guidelines and standards still need to be referred to with respect to IEQ and the renovation of the buildings.

It is recommended that POE should be undertaken in order to highlight the importance of IEQ and ensure its consideration in the refurbishment of pre-school buildings in order to improve early education for future generations. It is also recommended that there should be further analytical research into IEQ in refurbished pre-school buildings and study the correlation with occupants (the end-users of buildings used for early education) in Malaysia.

\section{References}

1. J. Gao, P, Wargocki, Y. Wang, Ventilation system type, classroom environmental quality and pupils' perceptions and symptoms. Building and Environment, 75(0), 46-57 (2014)

2. K.G. Rosěn, G. Richardson, Would removing indoor air particulates in children's environ-ment reduce rate of absenteeism- a hypothe-sis. The Science of the Total Environment, 234, 87-93 (1999)

3. S. Ambu, W, Chu, J. Mak, S, Wong, S.Chan., S. Wong, Review article: Environmental Health And Building Related Illnesses [Electronic Version]. IeJSME, 2, 11-18. Retrieved 14 March 2012, from http://web.imu.edu.my/ejournal/approved/eJournal_2.S1_11-18.pdf

4. C. Uline, M. Tschannen-Moran, The walls speak: The interplay of quality facilities, school climate, and student achievement. Journal of Educational Administration, 46(1), 55-73 (2008)

5. D. Stankovic, J. Stojic, J. Psycho-developing needs of children and spatial features for children's stay, Architecture and Civil Engineering, 5(1), 71 - 75 (2007)

6. P. Wargocki, D.P. Wyon, B. Matysiak, S. Irgens, Proceedings of Indoor Air 2005. The Effects of Classrooms Temperature and Outdoor Air Supply Rate on the Performance of School Work by Children. The 10th International Conference In Indoor Air Quality and Climate, Beijing

7. M.J.Mendell, E. Eliseeva, M.M. Davies, M. Spears, A. Lobscheid, W.J.Fisk, M.G. Apte, Association of classroom ventilation with reduced illness absence: a prospective study in California elementary schools. Indoor Air, 23, 515-528.Lee, S., \& Chang, M. (1999). Indoor air quality investigations at five class-rooms. Indoor Air, 9, 134 - 138.

8. V. Straka, M. Aleksic, Post-Occupancy Evaluation, PLEA2009 - 26th Conference on Passive and Low Energy Architecture, Quebec City, Canada, 22-24 June 2009.

9. S. Lee, M. Chang, Indoor air quality investigations at five classrooms. Indoor Air, 9, 134 - 138(1999)
10. N.M. Salleh, S.N. Kamaruzzaman, M. Riley, E.M.A. Zawawi, R. Sulaiman, R. A quantitative evaluation of indoor environmental quality in refurbished kindergarten buildings: A Malaysian case study. Building and Environment 94, 723-733(2015)

11. A. Montazami, M. Wilson, N. Fergus, Air-craft noise, overheating and poor air quality in classrooms in London primary school. Build Environ, 52(2012), 129-141.

12. Puteh, M., Adnan, M., Ibrahim, M.H., \& Mohamed Noh, N. (2014) . Proceedings from 5th World Conference Educational Sciences-WCES 2013. An Analysis of comfortable teaching and learning environment: community re-sponse to climate change in school. Social and Behavioral Sciences, 116, $285-290$.

13. Kabir, E., Kim, K.H., Sohn, J.R., Kweon, B. Y., \& Shin, J. H. (2011). Indoor air quality assessment in child care and medical facilities in Korea. En-viron Monit : DOI 10.1007/s10661-011-2428-5

14. Sulaiman, M.A, Wan Yusoff, W.Z., Mahamud, N.A., \& Hamid, N.F. (2013). Proceedings from 5th In-ternational Conference on Humanities and Social Sciences. Impact of Indoor Environ-mental Quality (IEQ) on Academic Building to Psychology and Social of StudentsFaculty of Liberal Arts, Prince of Songkla University.

15. P.M. Bluyssen, The Indoor Environment Hand-book. London: RIBA Publishing (2009)

16. V.S.Chithra, S.M. Shiva Nagendra, Indoor air quality investigations in a naturally ventilated school building located close to an urban roadway in Chennai, India. Building and Environment 54, 159-167 (2012)

17. Mydin, M.A.O., Abdul Rahim, N., Ismail, M. (2012). "Evaluation of Indoor Environment Quality (IEQ) of Educational Buildings" Journal of Environment and Earth Science,2(8), 46- 54

18. Nasir, A. R. M., Musa, A. R., Che-Ani, A. I., Utaberta, N., Abdullah, N. A. G., \& Tawil, N. M. (2011). Identification of ilndoor environmental quali-ty (IEQ) parameter in creating conducive learning environment for architecture studio. Procedia Engineering, 20(0): 354-362

19. Mumovic, D., Palmer, J., Davies, M., Orme, M., Ridley, I., Oreszczyn, T., et al. (2009). Winter indoor air quality, thermal comfort and acoustic per-formance of newly built secondary schools in England. Building and Environment, 44(7), 1466-1477

20. D. Jarman, L. Webb, T.C. Chan, T.C. A beautiful school is a caring schools. School Bussiness Affairs. Retrieved 11 September 2011,from www.sba june_04_beautiful_schools.pdf/

21. R.J.Soughnessy, U,H. Soughnessy, Nevalainen, A., \& Moschandreas, D. (2006). A preliminary study on Association between ventilation rates in classrooms and students performance. Indoor Air, 16, 465-468.

22. Mors, S. T, Hensen, J. L.M., Loomans, M. G. L. C. \& Boerstra, A. C. (2011). Adaptive thermal com-fort in primary school classrooms: Creating and validating 
PMV-based comfort charts. Building and Environment, 46, 2454-2461.

23. S.N. Kamaruzzaman, S. N., R.A. Razak, Measur-ing indoor air quality performance in Malaysi-an government kindergarten. Journal of Build-ing Performance, 2(1) (2011)

24. Junaidah, Z., Lye, M.S., Jamal, H.H., \& Zailina, H. (2010). Allergy to air pollution and frequency of asthmatic attacks among asthmatic children. American-Eurasian Journal of Taxio-cological Sciences. 2(2), 83-92.

25. N.H.M. Hussin, L.M. Sann, M.N. Shamsudin, Z. Hashim, Characterization of Bacte-ria and Fungi Bioaerosol in the Indoor Air of Selected Primary Schools in Malaysia. Indoor and Built Environment (2011)

26. Kuala Lumpur City Hall. (2010), Senarai tadika swasta sediaada di WPKL. Jabatan Perancang Bandar. Unpublished

27. S. Sarantakos, Social Research, Palgrave, New York, NY. (1998).

28. Krejcie, R. V., \& Morgan, D. W. (1970). Determining sample size for research activities. Educational and Psychological Measurement, 30, 607-610.

29. Levermore G.J., Leventis M. (1998), Occupants feedback using a questionnaire rating liking and importance of up to 24 factors, CLIMA 2000 Brussels.

30. Levermore G.J.,(2000). Building energy management system: Application to low energy HVAC and natural ventilation control (2nd ed). UK: Department of Building Engineering, UMIST, E\&FN Spoon

31. Uniform Building By Law Act 1333, Laws of Malaysia, 16th ed., MDC Publisher, Kuala Lumpur, (2012). 